\title{
Molecular Characterization of Fusarium oxysporum and Fusarium commune Isolates from a Conifer Nursery
}

\author{
Jane E. Stewart, Mee-Sook Kim, Robert L. James, R. Kasten Dumroese, and Ned B. Klopfenstein
}

\begin{abstract}
First, second, and fifth authors: U.S. Department of Agriculture (USDA) Forest Service-Rocky Mountain Research Station, 1221 S. Main St., Moscow, ID 83843; third author: USDA Forest Service-Forest Health Protection, 3815 Schreiber Way, Coeur d'Alene, ID 83815; and fourth author: USDA Forest Service-Southern Research Station, 1221 S. Main, Moscow, ID 83843. Accepted for publication 18 May 2006.
\end{abstract}

\begin{abstract}
Stewart, J. E., Kim, M.-S., James, R. L., Dumroese, R. K., and Klopfenstein, N. B. 2006. Molecular characterization of Fusarium oxysporum and Fusarium commune isolates from a conifer nursery. Phytopathology 96:1124-1133.

Fusarium species can cause severe root disease and damping-off in conifer nurseries. Fusarium inoculum is commonly found in most container and bareroot nurseries on healthy and diseased seedlings, in nursery soils, and on conifer seeds. Isolates of Fusarium spp. can differ in virulence; however, virulence and colony morphology are not correlated. Forty-one isolates of Fusarium spp., morphologically indistinguishable from $F$. oxysporum, were collected from nursery samples (soils, healthy seedlings, and diseased seedlings). These isolates were characterized by amplified fragment length polymorphism (AFLP) and DNA sequencing of nuclear rDNA (internal transcribed spacer including 5.8S rDNA), mitochondrial rDNA (small subunit [mtSSU]), and nuclear translation elongation factor 1-alpha. Each isolate had a unique AFLP phenotype. Out of 121

sequences from all three regions and the combined data set showed that all highly virulent isolates clearly separated into a common clade that contained $F$. commune, which was recently distinguished from its sister taxon, $F$. oxysporum. Interestingly, all but one of the nonpathogenic isolates grouped into a common clade and were genetically similar to $F$. oxysporum. The AFLP cladograms had similar topologies when compared with the DNA-based phylograms. Although all tested isolates were morphologically indistinguishable from $F$. oxysporum based on currently available monographs, some morphological traits can be plastic and unreliable for identification of Fusarium spp. We consider the highly virulent isolates to be $F$. commune based on strong genetic evidence. To our knowledge, this is the first reported evidence that shows $F$. commune is a cause of Fusarium disease (root rot and damping-off) on Douglas-fir seedlings. Furthermore, several AFLP genetic markers and mtSSU sequences offer potential for development of molecular markers that could be used to detect and distinguish isolates of $F$. oxysporum nonpathogenic to conifers and highly virulent isolates of $F$. commune in forest nurseries.
\end{abstract} loci, 111 (92\%) were polymorphic; 30 alleles were unique to only highly virulent isolates and 33 alleles were unique to only isolates nonpathogenic on conifers. Maximum parsimony and Bayesian analyses of DNA
Additional keywords: forest pathology, molecular diagnostics, phylogenetics.
Fusarium species can behave as a fungal pathogen causing damping-off and root rot of young conifer seedlings, resulting in severe crop and economic losses in forest nurseries. It is one of the most important soilborne pathogens within nurseries throughout western North America (29). This fungal genus is ubiquitous in most container and bareroot nurseries on healthy and diseased conifer seedlings, in nursery soils, and on conifer seeds of several species, especially Douglas-fir (Pseudotsuga menziesii (Mirb.) Franco), western white pine (Pinus monticola Dougl.), and ponderosa pine (Pinus ponderosa Dougl. ex Laws.) (25).

Efforts to improve disease control within tree nurseries have been hampered because of the inability to characterize and quantify Fusarium spp. populations with regard to disease potential. Laboratory assays were developed to assess pathogenicity of Fusarium spp. isolates on conifer germinants (24). Representative Fusarium spp. isolates were collected from conifer seedling nurseries, evaluated for pathogenicity using these techniques, and found to vary greatly in virulence; some isolates were highly virulent, whereas others were nonpathogenic (29). Furthermore, highly virulent isolates could not be differentiated from other isolates based on morphology in culture. In a previous

Corresponding author: M.-S. Kim; E-mail address: mkim@fs.fed.us

DOI: 10.1094/PHYTO-96-1124

This article is in the public domain and not copyrightable. It may be freely reprinted with customary crediting of the source. The American Phytopathological Society, 2006. report, both highly virulent and nonpathogenic isolates were identified as $F$. oxysporum, based on morphology $(29,42)$. Although total $F$. oxysporum Schlechtend:Fr. populations could be estimated quantitatively, population levels were not necessarily correlated with the resulting damage that occurred in the nursery crop (25). Thus, methods are needed to identify and quantify populations of highly virulent Fusarium spp.

Molecular genetic techniques can be used to study population structure by examining many traits and revealing information unobtainable by other methods. Molecular markers have been used to compare genetic relationships to pathogenicity in many groups of fungi $(3,37)$. Previous studies used molecular techniques to differentiate pathogenic from nonpathogenic isolates of F. oxysporum f. sp. phaseoli (55) and other formae speciales of $F$. oxysporum $(4-6,35,38,41,52)$. Genetic differences between pathogenic and nonpathogenic strains of $F$. oxysporum found on conifers were previously examined using the histone-H3 encoding gene and amplified fragment length polymorphisms (AFLPs), and a few genetic differences between high-virulence and low-virulence/nonpathogenic isolates were found (11). These previous results suggested that molecular genetic techniques could perhaps be used to separate these two phenotypes. Furthermore, these techniques can be used to compare the phylogenetic relationships of highly virulent Fusarium spp. isolates on conifers from isolates within the $F$. oxysporum species complex. These techniques and tools can also determine if these populations are clonal, which may aid in disease management. 
Development of a genetic marker system to distinguish highly virulent and nonpathogenic isolates would prove useful for managing Fusarium root rot in conifer seedlings and a variety of other crops $(6,10)$. Sensitive molecular markers could allow for more cost-effective detection and quantification of the pathogen than conventional methods (33). With such molecular tools, nursery managers could estimate population levels of highly virulent isolates, and thereby better predict disease potential for the current growing season $(29,43)$. Little progress has been made toward developing simple and effective molecular markers for detecting and quantifying highly virulent pathogen populations within conifer nurseries (51).

The aim of this study was to examine the genetic relationships of pathogenic (low, moderate, and high virulence) and nonpathogenic isolates of Fusarium spp. that appeared morphologically indistinguishable from $F$. oxysporum, collected from soil and Douglas-fir seedlings. Genetic relationships were analyzed using AFLP and DNA sequencing of the nuclear encoded rDNA (internal transcribed spacer including 5.8S [ITS+5.8S]) and nuclear translation elongation factor 1-alpha (EF-1 $\alpha$ ), and the mitochondrial encoded rDNA (small subunit [mtSSU]). Specific objectives were to (i) determine if highly virulent isolates of Fusarium spp. represent a genetically distinct group; and (ii) evaluate potential utility of DNA sequences and AFLP markers to distinguish highly virulent isolates of Fusarium spp. The development of molecular markers would facilitate studies on population structure and aid nursery management by identifying isolates that are highly virulent or nonpathogenic on conifers.

\section{MATERIALS AND METHODS}

Fungal isolates and pathogenicity tests. Isolates of Fusarium spp. were collected from a forest nursery in Idaho during 1992 to 1998. A total of 100 isolates of Fusarium spp., collected from soil or roots of either healthy (nonsymptomatic) or diseased conifer seedlings, were evaluated. All 100 isolates were previously classified as F. oxysporum based on morphological characteristics (42). Isolates were previously evaluated for pathogenicity on Douglasfir germinants in laboratory tests (29) using a technique for rapid laboratory assessment for virulence (24).

Briefly, Douglas-fir germinants (recently germinated seeds) were exposed to a cornmeal-perlite inoculum (1:50, wt/wt mixture of inoculum to medium) for each fungal isolate, and disease symptoms were monitored and evaluated over a period of 14 days. Germinants were considered diseased when they displayed standard postemergence damping-off (death) or rotting of the radicle when examined during or at the end of the test. Germinants with damping-off symptoms received higher ratings than those with rotting of the radicle. Three disease categories were used for these assays: damping-off, radicle rotting, and no disease. Numbers were given to germinants in each category, which were then added to other criteria (length of time germinants survived, primary root growth, and re-isolation of inoculated isolates) for a final virulence rating (24). The possible numerical rating ranged from 0 to 100 , with higher values reflecting greater virulence. Each isolate had an average rating of numerical virulence that was used to compare isolates. Based on previous studies (26-28), highly virulent isolates exhibited scores of 80 to 100 , moderately virulent isolates from 60 to 79 , isolates with low virulence from 40 to 59 , and isolates with average scores below 39 were considered nonpathogenic. Detailed methods are described in James et al. (29).

A total of 41 of the 100 isolates were selected to represent the following criteria: (i) diversity of sources (i.e., soil, healthy seedlings, and diseased seedlings) and (ii) availability of virulence ratings (high virulence versus medium-low virulence versus nonpathogenic). Of these selected isolates, 16 exhibited high virulence, three isolates were moderately virulent, five isolates had low virulence, and 17 were deemed nonpathogenic to Douglas-fir seedlings (Table 1). As possible outgroups for phylogenetic and genetic analyses, we included single isolates of $F$. oxysporum f. sp. melonis (0348), F. oxysporum f. sp. lactucae (0349), F. oxysporum f. sp. lycopersici (0350), a nonpathogenic isolate of $F$. oxysporum (Fo47) currently used as a biological control for pathogenic isolates of $F$. oxysporum $(7,16)$, and three isolates of $F$. proliferatum $(9223 \mathrm{~F}, 9721 \mathrm{~B}$, and $9816 \mathrm{~A})$ (Table 1$)$.

DNA extraction. In preparation for DNA extraction, isolates were placed on $0.2-\mu \mathrm{m}$-pore nylon filters (Millipore Corp., Billerica, MA) to avoid direct contact with potato dextrose agar medium in a petri dish and incubated at $22^{\circ} \mathrm{C}$ for 1 week. Approximately $100 \mathrm{mg}$ of fresh mycelia was scraped from the nylon membrane for DNA extraction and purification with DNeasy Plant Mini DNA extraction kits following the manufacturer's protocol (Qiagen Inc., Valencia, CA). DNA was quantified using a TD-360 fluorometer (Turner Designs, Sunnyvale, CA).

AFLP Analyses. AFLP analyses were performed following the protocol of Vos et al. (53) with some modifications. For restriction digests, $350 \mathrm{ng}$ of genomic DNA was digested with EcoRI and MspI (New England BioLabs, Inc., Beverly, MA) to serve as the template. Resulting DNA fragments were ligated to adapters and diluted 1:10 with sterile distilled water prior to pre-amplification. Pre-amplifications were performed following protocols developed for Fusarium (3) and Armillaria species (34) with some modifications. Pre-amplification reaction mixtures (total $30 \mu \mathrm{l}$ ) contained $6 \mu$ of diluted restriction/ligation mixture as template, $1 \times$ polymerase chain reaction (PCR) buffer, $3 \mathrm{mM} \mathrm{MgCl} 2,200 \mu \mathrm{M}$ dNTPs, $300 \mathrm{nM}$ of each preselective primers (EcoRI-no extension and MspI-no extension), and 1.5 units of AmpliTaq DNA polymerase (Applied Biosystems, Inc., Foster City, CA). The PCR conditions for pre-amplification were $72^{\circ} \mathrm{C}$ for $2 \mathrm{~min}, 20$ cycles of $94^{\circ} \mathrm{C}$ for $30 \mathrm{~s}, 56^{\circ} \mathrm{C}$ for $30 \mathrm{~s}$, and $72^{\circ} \mathrm{C}$ for $1 \mathrm{~min} 30 \mathrm{~s}$ followed by a final step at $72^{\circ} \mathrm{C}$ for $10 \mathrm{~min}$.

For selective amplification, we chose two primers (EcoRIGC/MspI-CC and EcoRI-GC/MspI-CA) used by Baayen et al. (3). Selective amplification mixtures (total $25 \mu \mathrm{l}$ ) contained $5 \mu \mathrm{l}$ of diluted pre-amplification products (1:20 with low Tris-EDTA buffer [10 mM Tris-HCl, $0.1 \mathrm{mM}$ EDTA, $\mathrm{pH}$ 8.0]) as a template, $1 \times$ PCR buffer, $2.4 \mathrm{mM} \mathrm{MgCl} 2,300 \mu \mathrm{M}$ dNTPs, $100 \mathrm{nM}$ of EcoRI-GC primer, $300 \mathrm{nM}$ of MspI-CC or MspI-CA primers, and 1.25 units of AmpliTaq Gold polymerase (Applied Biosystems). Amplifications were performed using the following PCR conditions: $94^{\circ} \mathrm{C}$ for $2 \mathrm{~min}, 14$ cycles at $94^{\circ} \mathrm{C}$ for $30 \mathrm{~s}\left(1^{\circ} \mathrm{C}\right.$ per s to $\left.65^{\circ} \mathrm{C}\right), 65^{\circ} \mathrm{C}$ for $30 \mathrm{~s}\left(-0.7^{\circ} \mathrm{C}\right.$ per cycle $)$, and $72^{\circ} \mathrm{C}$ for $1 \mathrm{~min}$, 23 cycles at $94^{\circ} \mathrm{C}$ for $30 \mathrm{~s}, 56^{\circ} \mathrm{C}$ for $30 \mathrm{~s}$, and $72^{\circ} \mathrm{C}$ for $1 \mathrm{~min}$ (+1 s per cycle), and finally $72^{\circ} \mathrm{C}$ for $10 \mathrm{~min}$. All AFLP reactions were conducted using an MJ PTC-200 thermocycler (Bio-Rad Laboratories, Waltham, MA).

Selective amplification products were separated in an ABI 3700 DNA automated sequencer (Applied Biosystems) at the University of Wisconsin-Biotechnology Center (Madison, WI). Genotyper 3.7 NT (Applied Biosystems) was used to identify peaks with a fluorescent intensity greater than the threshold value (ca. 150 units) in at least one sample. Categories were made from these identified peaks for scoring samples.

AFLP bands were scored as present (1) or absent (0) using Genotyper 3.7 NT and a binary matrix was developed with molecular sizes ranging from 70 to $325 \mathrm{bp}$. Each band was checked visually using GeneScan 3.7 NT (Applied BioSystems). The resulting binary matrix was used to calculate Dice's similarity coefficients using NTSYS-pc version 2.1 (Exeter Software, Setauket, NY). Distances were graphically displayed by unweighted pairedgroup method with arithmetic means (UPGMA). Maximum parsimony analyses were also implemented with PAUP* 4.0b10 (Sinauer Publishing, Sunderland, MA) using the heuristic search option with 1,000 random addition sequences using the tree 
bisection-reconnection (TBR) branch swapping option. The MULPARS option was off (because of computer constraint) and all characters were weighted equally. Robustness and support for parsimony groupings were obtained using 1,000 bootstraps with random addition ( 10 replicates) for each heuristic search. The gel fragment size and binary data sets have been deposited into TreeBASE, as well as the UPGMA and parsimony trees (study accession no. S1494).

DNA sequencing. The ITS $+5.8 \mathrm{~S}, \mathrm{mtSSU}$, and EF- $1 \alpha$ regions were amplified using PCR. Primers ITS-1F/ITS-4 (17,54), MS1/ MS2 (54), and EF1/EF2 (46) were used to amplify the ITS+5.8S, $\mathrm{mtSSU}$, and EF-1 $\alpha$, respectively. Each $50-\mu \mathrm{l}$ reaction mixture contained $10 \mathrm{ng}$ of template DNA (or no DNA template for a negative control), 2.5 units of AmpliTaq DNA polymerase, 1× PCR buffer, $4 \mathrm{mM} \mathrm{MgCl} 2,200 \mu \mathrm{M}$ dNTPs, and $0.5 \mu \mathrm{M}$ of each primer. The PCR conditions were as follows: (i) for ITS $+5.8 \mathrm{~S}$, $95^{\circ} \mathrm{C}$ for $2 \mathrm{~min}, 30$ cycles at $94^{\circ} \mathrm{C}$ for $1 \mathrm{~min}, 54^{\circ} \mathrm{C}$ for $30 \mathrm{~s}$, and $72^{\circ} \mathrm{C}$ for $1 \mathrm{~min}$ followed by a final step at $72^{\circ} \mathrm{C}$ for $10 \mathrm{~min}$; (ii) for $\mathrm{mtSSU}, 94^{\circ} \mathrm{C}$ for $2 \mathrm{~min}, 35$ cycles at $94^{\circ} \mathrm{C}$ for $30 \mathrm{~s}, 52^{\circ} \mathrm{C}$ for $30 \mathrm{~s}$, and $72^{\circ} \mathrm{C}$ for $1 \mathrm{~min} 30 \mathrm{~s}$ followed by a final step at $72^{\circ} \mathrm{C}$ for $10 \mathrm{~min}$; and (iii) for $\mathrm{EF}-1 \alpha, 94^{\circ} \mathrm{C}$ for $2 \mathrm{~min}, 30$ cycles at $94^{\circ} \mathrm{C}$ for $1 \mathrm{~min}, 54^{\circ} \mathrm{C}$ for $30 \mathrm{~s}$, and $72^{\circ} \mathrm{C}$ for $1 \mathrm{~min}$ followed by a final step at $72^{\circ} \mathrm{C}$ for $10 \mathrm{~min}$. All reactions were conducted with an MJ PTC-200 thermocycler. PCR products were electrophoresed in

TABLE 1. Isolates of Fusarium oxysporum and F. commune used in this study

\begin{tabular}{|c|c|c|c|c|c|}
\hline Taxon & Collection $^{\mathrm{a}}$ & Isolate $^{b}$ & Host/substrate & Virulence rating $^{\mathrm{c}}$ & $\begin{array}{c}\text { GenBank accession no. } \\
(\mathrm{ITS}+5.8, \mathrm{mtSSU}, \mathrm{EF}-1 \alpha)\end{array}$ \\
\hline F. commune & $9245 \mathrm{H}$ & $F c-\mathrm{H} 1$ & Soil & High & DQ016195, DQ016145, DQ016242 \\
\hline F. commune & $9302 \mathrm{G}$ & $F c-\mathrm{H} 2$ & Soil & High & DQ016197, DQ016143, DQ016252 \\
\hline F. commune & 9313Q & $F c-\mathrm{H} 3$ & Soil & High & DQ016201, DQ016143, DQ016255 \\
\hline F. commune & $9312 \mathrm{~F}$ & $F c-\mathrm{H} 4$ & Soil & High & DQ016200, DQ016148, DQ016245 \\
\hline F. commune & $9302 \mathrm{~A}$ & $F c-\mathrm{H} 5$ & Soil & High & DQ016196, DQ016144, DQ016254 \\
\hline F. commune & 9312D & $F c-\mathrm{H} 6$ & Soil & High & DQ016191, DQ016146, DQ016253 \\
\hline F. commune & 9447B & $F c-\mathrm{H} 7$ & Soil & High & DQ016203, DQ016151, DQ016256 \\
\hline F. commune & $9447 \mathrm{G}$ & $F c-\mathrm{H} 8$ & Soil & High & DQ016204, DQ016152, DQ016247 \\
\hline F. commune & $9447 \mathrm{~J}$ & $F c-\mathrm{H} 9$ & Soil & High & DQ016199, DQ016147, DQ016244 \\
\hline F. commune & $9448 \mathrm{M}$ & $F c-\mathrm{H} 10$ & Soil & High & DQ016205, DQ016153, DQ016251 \\
\hline F. commune & 9449A & $F c-\mathrm{H} 11$ & Soil & High & DQ016206, DQ016154, DQ016250 \\
\hline F. commune & $9526 \mathrm{E}$ & $F_{c}-\mathrm{H} 12$ & Soil & High & DQ016208, DQ016156, DQ016248 \\
\hline F. commune & $9665 \mathrm{~K}$ & $F c-\mathrm{H} 13$ & Soil & High & DQ016210, DQ016158, DQ016258 \\
\hline F. commune & $9408 \mathrm{~A}$ & $F c-\mathrm{H} 14$ & Douglas-fir (diseased) & High & DQ016202, DQ016150, DQ016246 \\
\hline F. commune & $9458 \mathrm{~B}$ & $F_{c}-\mathrm{H} 15$ & Douglas-fir (healthy) & High & DQ016207, DQ016155, DQ016257 \\
\hline F. commune & $9613 \mathrm{~A}$ & $F c-\mathrm{H} 16$ & Douglas-fir (healthy) & High & DQ016209, DQ016157, DQ016249 \\
\hline F. oxysporum & $9315 \mathrm{G}$ & Fo-M1 & Soil & Medium & DQ016212, DQ016161, DQ016259 \\
\hline F. commune & $9312 \mathrm{H}$ & $F c-\mathrm{M} 2$ & Soil & Medium & DQ016211, DQ016159, DQ016243 \\
\hline F. oxysporum & 9348A & Fo-M3 & Soil & Medium & DQ016213, DQ016160, DQ016260 \\
\hline F. oxysporum & $9411 \mathrm{C}$ & $F o-\mathrm{L} 1$ & Soil & Low & DQ016216, DQ016164, DQ016263 \\
\hline F. oxysporum & $9302 \mathrm{E}$ & Fo-L2 & Soil & Low & DQ016214, DQ016165, DQ016261 \\
\hline F. oxysporum & $9447 \mathrm{E}$ & Fo-L3 & Soil & Low & DQ016217, DQ016163, DQ016264 \\
\hline F. oxysporum & $9665 \mathrm{~J}$ & Fo-L4 & Soil & Low & DQ016218, DQ016166, DQ016265 \\
\hline F. oxysporum & $9312 \mathrm{~L}$ & Fo-L5 & Soil & Low & DQ016215, DQ016162, DQ016262 \\
\hline F. oxysporum & $9343 \mathrm{~A}$ & $F o-\mathrm{N} 1$ & Soil & Non & DQ016219, DQ016170, DQ016267 \\
\hline F. oxysporum & 9343E & $F o-\mathrm{N} 2$ & Soil & Non & DQ016192, DQ016169, DQ016266 \\
\hline F. oxysporum & $9343 \mathrm{G}$ & $F o-\mathrm{N} 3$ & Soil & Non & DQ016220, DQ016171, DQ016268 \\
\hline F. oxysporum & $9348 \mathrm{~F}$ & Fo-N4 & Soil & Non & DQ016221, DQ016172, DQ016269 \\
\hline F. oxysporum & 9348J & $F o-\mathrm{N} 5$ & Soil & Non & DQ016222, DQ016173, DQ016270 \\
\hline F. oxysporum & $9411 B$ & Fo-N6 & Soil & Non & DQ016223, DQ016174, DQ016271 \\
\hline F. oxysporum & $9448 \mathrm{~J}$ & Fo-N7 & Soil & Non & DQ016194, DQ016167, DQ016274 \\
\hline F. oxysporum & 9449C & $F o-\mathrm{N} 8$ & Soil & Non & DQ016226, DQ016176, DQ016275 \\
\hline F. oxysporum & 9449D & Fo-N9 & Soil & Non & DQ016227, DQ016177, DQ016276 \\
\hline F. oxysporum & $9449 \mathrm{E}$ & $F o-\mathrm{N} 10$ & Soil & Non & DQ016228, DQ016178, DQ016277 \\
\hline F. oxysporum & 9449F & Fo-N11 & Soil & Non & DQ016229, DQ016179, DQ016278 \\
\hline F. oxysporum & $9449 \mathrm{H}$ & Fo-N12 & Soil & Non & DQ016230, DQ016180, DQ016279 \\
\hline F. oxysporum & $9449 \mathrm{~K}$ & Fo-N13 & Soil & Non & DQ016231, DQ016181, DQ016280 \\
\hline F. oxysporum & $9450 \mathrm{~A}$ & Fo-N14 & Soil & Non & DQ016232, DQ016182, DQ016281 \\
\hline F. oxysporum & $9418 \mathrm{C}$ & Fo-N15 & Douglas-fir (diseased) & Non & DQ016193, DQ016168, DQ016272 \\
\hline F. oxysporum & 9418D & $F o-\mathrm{N} 16$ & Douglas-fir (diseased) & Non & DQ016224, DQ016175, DQ016273 \\
\hline F. commune & $9418 \mathrm{E}$ & $F_{c}-\mathrm{N} 17$ & Douglas-fir (diseased) & Non & DQ016198, DQ016142, DQ016241 \\
\hline F. oxysporum f. sp. melonis ${ }^{\mathrm{d}}$ & 0348 & $\ldots$ & Melon & N/A & DQ016233, DQ016183, DQ016282 \\
\hline F. oxysporum f. sp. lactucae $\mathrm{d}^{\mathrm{d}}$ & 0349 & $\ldots$ & Lettuce & N/A & DQ016234, DQ016184, DQ016283 \\
\hline F. oxysporum f. sp. lycopersici ${ }^{\mathrm{d}}$ & 0350 & $\ldots$ & Tomato & N/A & DQ016235, DQ016185, DQ016284 \\
\hline F. oxysporum ${ }^{\mathrm{e}}$ & Fo47 & Fo-Fo47 & Soil & Non & DQ016236, DQ016186, DQ016285 \\
\hline F. proliferatum & $9223 \mathrm{~F}$ & $\ldots$ & Aspen & High & DQ016238, DQ016188, DQ016287 \\
\hline F. proliferatum & $9721 \mathrm{~B}$ & $\ldots$ & Douglas-fir & High & DQ016239, DQ016189, DQ016288 \\
\hline F. proliferatum & 9816 & $\ldots$ & Whitebark pine & High & DQ016240, DQ016190, DQ016289 \\
\hline
\end{tabular}

a All isolates were collected in Idaho, except isolates 0348, 0349, and 0350, which were collected in California, and isolate Fo47, which was collected in France.

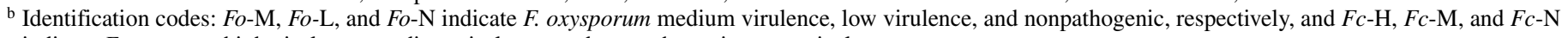
indicate $F$. commune high virulence, medium virulence, and nonpathogenic, respectively.

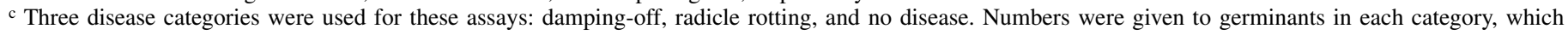
were then added to other criteria (length of time germinants survived, primary root growth, and re-isolation of inoculated isolates) for a final virulence rating (24). The possible numerical rating ranged from 0 to 100 , with higher values reflecting greater virulence. Each isolate had an average rating of numerical virulence that was used to compare isolates. Based on previous studies (26-28), highly virulent isolates exhibited scores of 80 to 100 , moderately virulent isolates from 60 to 79, isolates with low virulence from 40 to 59, and isolates with average scores below 39 were considered nonpathogenic.

${ }^{\mathrm{d}}$ Isolates 0348,0349 , and 0350 were collected by T. Gordon in pathogenic situations.

e Isolate Fo47 was collected by C. Alabouvette and has been used as a biological control against pathogenic isolates of F. oxysporum. 
$1.5 \%$ agarose gels with $0.5 \times$ Tris-borate-EDTA $(89 \mathrm{mM}$ Tris, $89 \mathrm{mM}$ boric acid, and $2 \mathrm{mM}$ EDTA) buffer. Gels were stained with ethidium bromide $(0.5 \mu \mathrm{g} / \mathrm{ml})$ and bands were visualized using UV light. PCR products were treated with ExoSAP-IT (USB Corporation, Cleveland, $\mathrm{OH}$ ) and sequenced with an ABI 3700 DNA sequencer at the Davis Sequencing Facility (Davis, CA) and the University of Wisconsin-Biotechnology Center. All regions were sequenced with the same primers used for initial amplification.

Phylogenetic analyses. Raw sequences from both strands were aligned and edited visually using BioEdit (19). Alignments of sequences were also examined using Clustal X Multiple Sequence Alignment Program version 1.81 (30). Any duplicate sequence types were removed from the data set prior to phylogenetic analyses. All sequences used for phylogenetic analyses were deposited into GenBank (Table 1).

Phylogenetic analyses were conducted using PAUP and MrBayes version 3.0b4 (23). The ITS+5.8S, mtSSU, and EF-1 $\alpha$ regions were analyzed separately and combined (excluding the ITS $+5.8 \mathrm{~S}$ region). For the combined analyses, sequences (mtSSU and EF-1 $\alpha$ ) of four isolates of $F$. oxysporum (NRRL 31073, AF362290 for mtSSU/AF362274 for EF-1 $\alpha$; NRRL 31074, AF362289/AF362273; NRRL 26442, AF250562/AF246834; and NRRL 25603, AF008453/AY527534), one isolate of $F$. oxysporum f. sp. batatas (NRRL 26409, AF008450/AF008484) (47), one isolate of $F$. oxysporum f. sp. lycopersici (NRRL 26383, AF008468/AF008502) (47), one isolate of $F$. oxysporum $\mathrm{f}$. sp. melonis (NRRL 26406, AF008470/AF008504) (47), six isolates of $F$. commune Skovgaard, O'Donnell et Nirenberg (NRRL 22900, AF362288/AF362272; NRRL 22903, U34509/AF008513; NRRL 25043, AF362277/AF362261; NRRL 26897, AF362286/ AF362270; NRRL 28058, AF324293/AF324333; and NRRL 31081, AF362285/AF362269) (49), and one isolate of F. subglutinans (NRRL 22016, M1431/AF160289) were obtained from GenBank. Sequences of $F$. subglutinans were found in a matrix (M1431) from TreeBASE (49) and included in the analyses for comparison. Care was taken to ensure sequences of the mtSSU and EF- $1 \alpha$ regions were from the same isolate. An isolate of F. redolens (NRRL 31255, M1431/M1432 from TreeBASE) served as the outgroup. All indels within the sequence alignment were coded using a simple gap-coding method (48). Maximum parsimony and Bayesian analyses were performed on all regions to search for optimal trees. Maximum parsimony analyses were performed using the heuristic search option with 1,000 random addition sequences using TBR branch swapping with the MULPARS option on, and all characters were weighted equally. Robustness and support for parsimony groupings were obtained using 1,000 bootstraps with random addition (10 replicates) for each heuristic search. DT-ModSel (39) was used to determine nucleotide substitution models best suited for the data sets. Model selections for ITS+5.8S, mtSSU, and EF-1 $\alpha$ were TrNef, HKY+I, and $\mathrm{K} 80+\mathrm{I}$, respectively. These models were used for Bayesian analysis, which was performed with settings suggested by the selected models. For Bayesian analyses, the Markov chain Monte Carlo search was run with four chains for 3,000,000 generations generating 30,001 trees, the first 6,000 trees were discarded as "burnin" of the chains. The remaining 24,001 trees were used to make $90 \%$ majority-rule consensus trees using PAUP. Preliminary analyses for the ITS+5.8S showed, however, that the highly virulent isolates of Fusarium sp. clustered with $F$. proliferatum. For this reason, we obtained a sequence for $F$. beomiforme from GenBank (U61674) to serve as the outgroup for analyses of the ITS+5.8S region. Partition-homogeneity test implemented using PAUP was conducted to evaluate concordance and combinability of the mtSSU and EF-1 $\alpha$ data sets $(15,22)$. Partition-homogeneity test, which corresponds to the incongruence length difference (ILD) test $(9,14)$, was conducted using 1,000 heuristic searches with random addition sequence and TBR branch swapping. The
MULPARS option was not in effect because of computer memory constraints. Parsimony and Bayesian analyses were completed on the combined data. Maximum parsimony analysis was completed on the combined data set with identical options in effect for the separate regions. Again, DT-ModSel was used to determine that $\mathrm{SYM}+\mathrm{I}+\mathrm{G}$ was the best-suited nucleotide-substitution model for the combined data set. Bayesian analyses were performed using MrBayes with settings suggested by the selected model. For Bayesian analyses, the Markov chain Monte Carlo search was run with four chains for 3,000,000 generations generating 30,001 trees, the first 6,000 trees were discarded as "burnin" of the chains. The remaining 24,001 trees were used to make a $90 \%$ majority-rule consensus tree using PAUP. All phylogenetic trees generated from rDNA sequence data have been deposited into TreeBASE (study accession no. S1494).

\section{RESULTS}

AFLP analyses. Analysis of two selective primer combinations yielded a total of 146 presumptive loci for all 48 isolates included in the analyses, 41 Fusarium spp. isolates, one isolate of $F$. oxysporum $\mathrm{f}$. sp. melonis (0348), one isolate of $F$. oxysporum $\mathrm{f}$. sp. lactucae (0349), one isolate of $F$. oxysporum f. sp. lycopersici (0350), one nonpathogenic isolate of $F$. oxysporum ( $F o$-Fo47), and three isolates of $F$. proliferatum $(9223 \mathrm{~F}, 9721 \mathrm{~B}$, and $9816 \mathrm{~A})$. Of the 146 AFLP loci, 142 (97.3\%) were polymorphic. Each of the 48 isolates had a unique AFLP phenotype. Examinations of the 41 isolates from the conifer nursery (Table 1) yielded a total of 121 presumptive loci, of which 111 (92\%) loci were polymorphic. Of the 111 polymorphic AFLP loci evaluated, 30 alleles were unique to only highly virulent isolates $(F c-\mathrm{H} 1$ to $F c-\mathrm{H} 16)$ and 33 alleles were unique to only nonpathogenic isolates $(F o-\mathrm{N} 1$ to $F o$-N16). The AFLP phenotype for one isolate $(F c-\mathrm{N} 17$; nonpathogenic), however, showed similarity to AFLP phenotypes for highly virulent isolates; this was the only nonpathogenic isolate that clustered with highly virulent isolates (Table 1; Figs. 1 to 5). A cluster analysis using UPGMA identified two groups of isolates (Fig. 1). The first group included all nonpathogenic isolates (except $F c$-N17), all isolates of low virulence, and most isolates of moderate virulence, whereas the second group contained all highly virulent isolates $(F c-\mathrm{H} 1$ to $F c$-H16), one moderately virulent isolate $(F c-\mathrm{M} 2)$, and one nonpathogenic isolate (Fc-N17) (Fig. 1).

DNA sequencing. Each sequenced region (ITS+5.8S, mtSSU, and EF-1 $\alpha$ ) had a different number of unique haplotypes used for the analyses (Table 2). The ITS+5.8S region had six unique haplotypes and analyzed sequences were 94 to $99 \%$ similar. Of this region's 534 characters, 35 (6\% of the total) of 50 variable characters were parsimony informative. The mtSSU region had seven haplotypes, with sequences that were 94 to $99 \%$ similar. Of the mtSSU region's 652 characters, 46 (7\% of the total) of 47 variable characters were parsimony informative. The EF- $1 \alpha$ region had 17 unique haplotypes and 669 characters; all 71 (11\% of the total) variable characters were parsimony informative. Results from the partition homogeneity test indicated that mtSSU and EF$1 \alpha$ were congruent and could be combined $(P=0.104)$. The combined data set yielded 35 unique haplotypes with 117 (9\%) informative and 84 uninformative characters (Table 2).

Phylogenetic analyses. Maximum parsimony and Bayesian analyses on ITS $+5.8 \mathrm{~S}, \mathrm{mtSSU}$, and EF- $1 \alpha$ yielded similar results (Figs. 2 to 4). Bayesian analyses tended to generate a more conservative phylogram dependent on the majority-rule posterior probability cutoffs at $90 \%$ compared with $50 \%$ bootstrap cutoffs used for parsimony analyses. For all regions, however, separation of the highly virulent isolates into a single clade was consistently supported with bootstrapping of over $80 \%$ (Figs. 2 to 4 ). All nonpathogenic isolates, with the exception of $F c$-N17, also clustered within a common clade. In addition, all low to moderately 
virulent isolates also grouped with the nonpathogenic isolates, with the exception of $F c$-M2, which consistently clustered within the highly virulent clade (Figs. 2 to 4 ). A heuristic search, with the optimality criterion set to parsimony in PAUP, found 10 equally parsimonious trees for the EF- $1 \alpha$ region; one parsimonious tree was found when the ITS+5.8S and mtSSU regions were analyzed.

The number of clusters within a clade, and the cluster each isolate nested into, varied depending on the DNA region analyzed. For example, the clade comprising nonpathogenic isolates with some low to moderately virulent isolates, contained eight clusters based on the EF- $1 \alpha$ region, but only four and five clusters based on the ITS+5.8S and mtSSU regions, respectively (Figs. 2 to 4). With the EF- $1 \alpha$ and $\mathrm{mtSSU}$ regions, the three $F$. proliferatum isolates formed a separate cluster. Isolates from other $F$. oxysporum formae speciales, $F$. oxysporum $\mathrm{f}$. sp. lactucae, $F$. oxysporum $\mathrm{f}$. sp. melonis, $F$. oxysporum f. sp. lycopersici, and nonpathogenic isolate $(\mathrm{Fo}$-Fo47) clustered within the same clade for all regions. In the ITS+5.8S region, few polymorphisms were observed between sequences of highly virulent and nonpathogenic isolates.
Sequences of highly virulent $F$. oxysporum and $F$. proliferatum differed by only three base pairs, and $F$. oxysporum and $F$. proliferatum were clustered together in the phylogenetic analysis of the ITS+5.8S region (Fig. 2).

The combined data set of mtSSU and EF- $1 \alpha$ and the AFLP cladograms had similar topologies when compared with the other regions analyzed (Figs. 1 and 5). Cladograms produced using maximum parsimony displayed two distinct clades: one contained all the highly virulent isolates with one nonpathogenic isolate and one moderately virulent isolate. The second clade contained nonpathogenic and low to moderately virulent isolates, which were again supported with bootstrapping of over $88 \%$ (Figs. 1 and $5)$. Sequences for isolates within the $F$. oxysporum species complex (obtained from GenBank) clustered within the nonpathogenic clade, whereas sequences of $F$. commune isolates (obtained from GenBank and TreeBASE) clustered within the highly virulent clade. In fact, two highly virulent isolates $(F c-\mathrm{H} 2$ and $F c$ H6) shared an identical sequence type with $F$. commune isolate NRRL 22903 (Fig. 5). A heuristic search, with the optimality criterion set to parsimony in PAUP, found eight equally parsi-

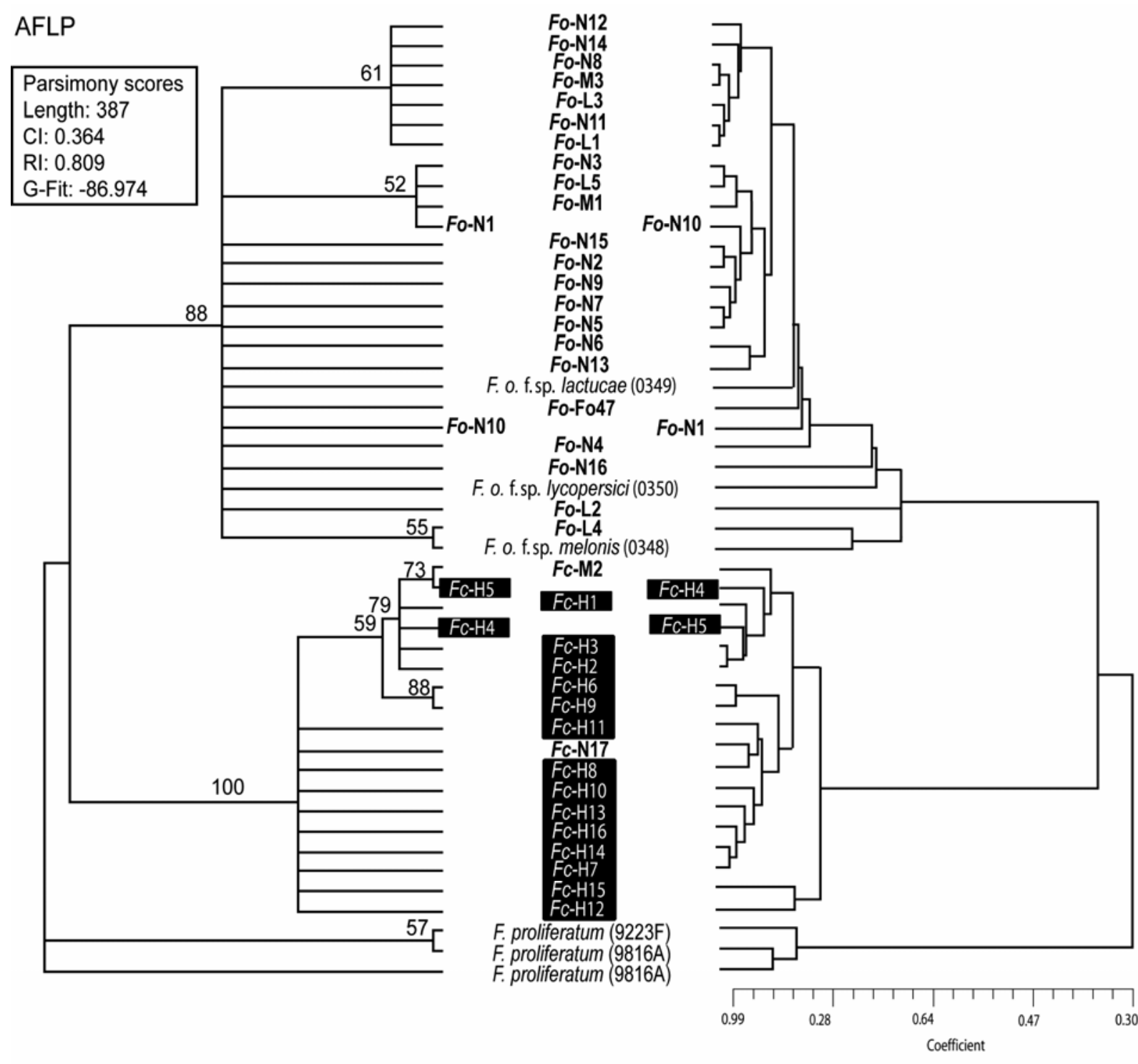

Parsimony

UPGMA

Fig. 1. Parsimony and unweighted pair-group method with arithmetic average (UPGMA, right) trees generated from amplified fragment length polymorphism (AFLP) data. Isolates of Fusarium oxysporum $(F o$ ) and $F$. commune $(F c)$ are described in Table 1. Bold numbers represent $F o$ and $F c$ isolates and boxed numbers represent highly virulent $F c$ isolates used in our study. The image shows a 50\% majority-rule bootstrap support for maximum parsimony analysis based on 1,000 bootstraps (left). 
monious trees when using the combined data set and 1,560 equally parsimonious trees when using the AFLP binary data set.

Phylogenetic species recognition. DNA sequence data from $\mathrm{mtSSU}$ and EF-1 $\alpha$ indicated that the highly virulent isolates $(F c$ $\mathrm{H} 1-\mathrm{H} 16)$, one nonpathogenic $(F c-\mathrm{N} 17)$, and one moderately virulent isolate ( $F c$-M2) appeared to be $F$. commune (Fig. 5) that was recently distinguished from its putative sister taxon, $F$. oxysporum (49). Most of our nonpathogenic (Fo-N1-N16), low (Fo-L1-L5) and moderately virulent $(F o-\mathrm{M} 1, F O-\mathrm{M} 3)$ isolates appeared to be F. oxysporum (Fig. 5).

\section{DISCUSSION}

Based on AFLP markers and DNA sequences of ITS+5.8S, $\mathrm{mtSSU}$, and EF- $1 \alpha$ regions, we determined that highly virulent isolates that caused damping-off and root rot on Douglas-fir seedlings were $F$. commune, although they were originally classified as $F$. oxysporum based on morphology. Those isolates were genetically distinct from nonpathogenic isolates of $F$. oxysporum collected from the same forest nursery. Furthermore, mtSSU or EF-1 $\alpha$ sequence data or AFLP markers showed potential utility for identifying highly virulent $F$. commune isolates among populations of Fusarium spp. collected from conifer seedlings or nursery soil. Nearly 30 and 33 AFLP loci were unique to only highly virulent and nonpathogenic isolates, respectively. Unique loci associated with highly virulent isolates could be sequenced and used to develop diagnostic primers for identifying highly virulent isolates of $F$. commune within the nursery setting.

Sequences of the ITS $+5.8 \mathrm{~S}$ region allowed us to distinguish highly virulent isolates from most nonpathogenic isolates (collected from soil and Douglas-fir roots), but this region was not useful for differentiating highly virulent isolates from $F$. proliferatum. O'Donnell and Cigelnik (45) showed that species within the Gibberella fujikuroi complex, which includes $F$. proliferatum, contain two nonorthologous copies of ITS, type 1 and type 2 . Our study showed that $F$. proliferatum and our isolates of $F$. commune contain ITS type 2 , while nonpathogenic isolates of $F$. oxysporum contain ITS type 1 . Low and moderately virulent

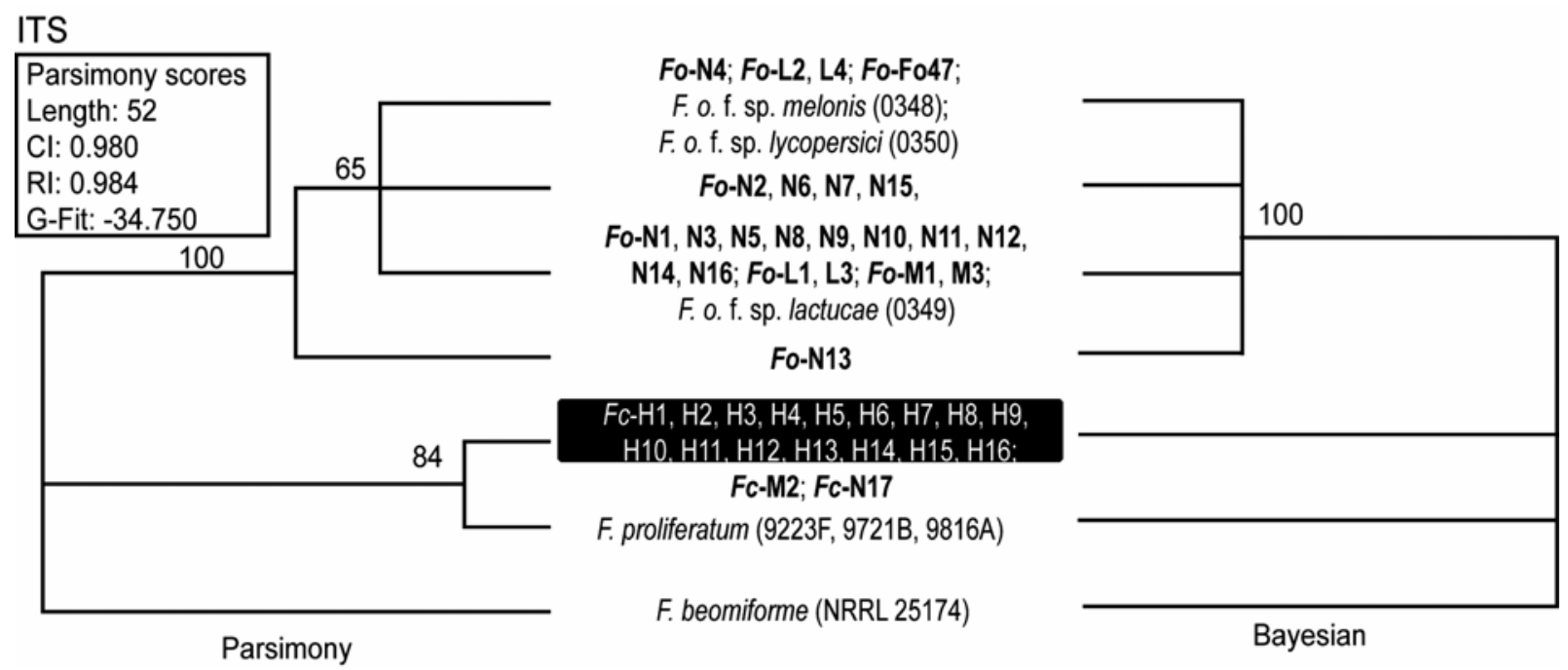

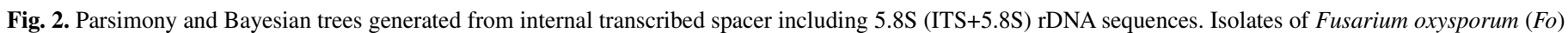

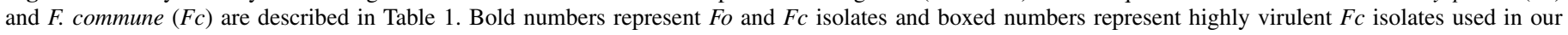

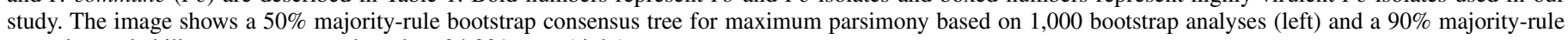
posterior probability consensus tree based on 24,001 trees (right).

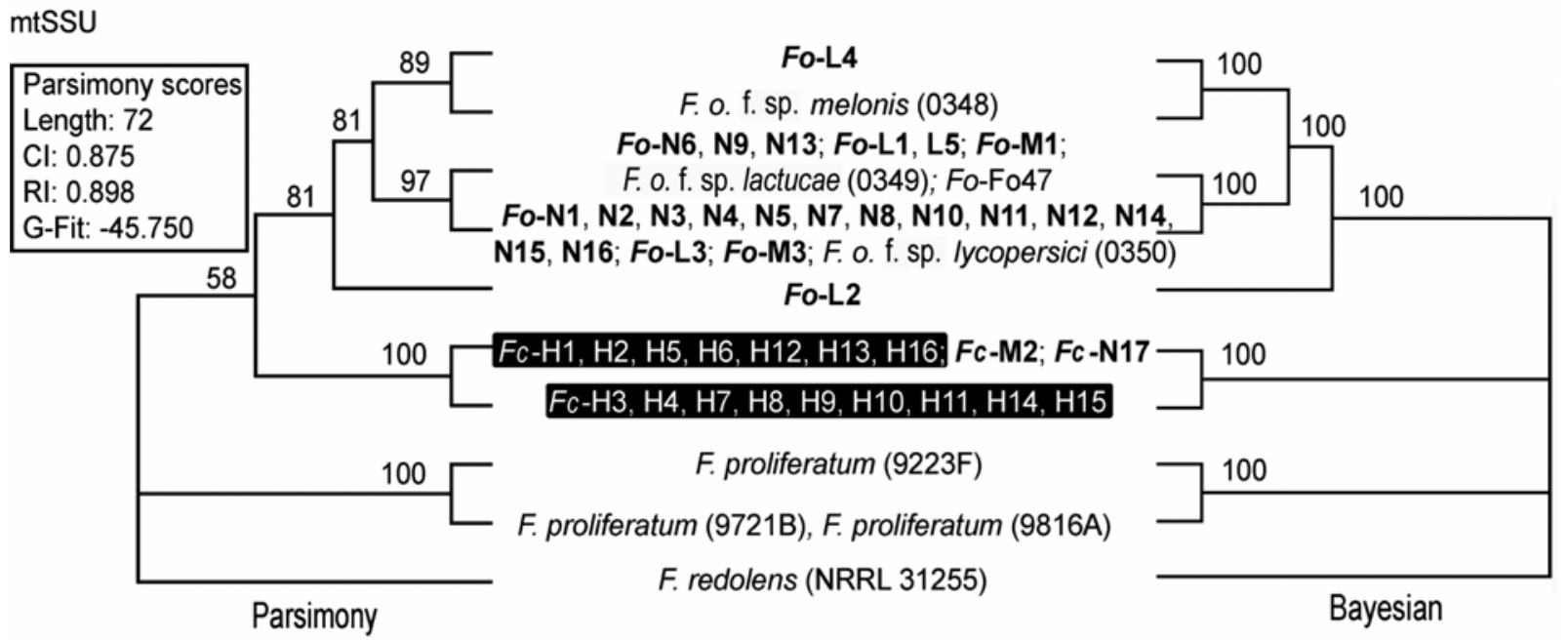

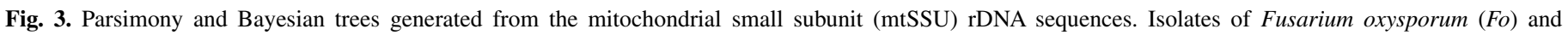

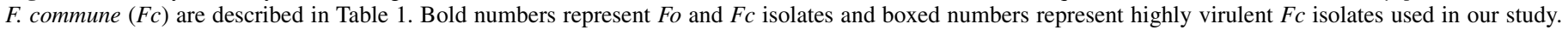

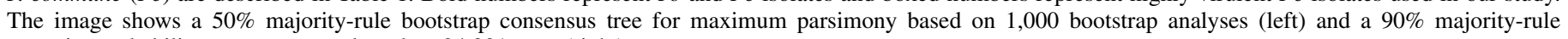
posterior probability consensus tree based on 24,001 trees (right). 
isolates contained ITS type 1 or ITS type 2, depending on their similarity to either $F$. commune or $F$. oxysporum. The heterogeneity of intergenic spacer and ITS regions within single genomes or among strains has been reported in several groups of fungi $(1,32,34,36,44)$. Sequence heterogeneity can confound phylogenetic analysis, so meticulous care is needed to recognize and interpret such heterogeneity (34). Bao et al. (5) showed that the ITS+5.8S region could not distinguish between the isolates previously used as a biocontrol agent (7) and other nonpathogenic isolates of F. oxysporum. Similar results were found in our study; isolate $\mathrm{Fo}-\mathrm{Fo} 47$, previously used as a biocontrol agent against virulent $F$. oxysporum strains $(7,16)$, grouped with our isolates that were nonpathogenic on conifers for all regions analyzed (Figs. 2 to 4). Although all of these nonpathogenic isolates appeared closely related genetically, the nonpathogenic isolates in this study have not been tested for potential biocontrol effects. Such evaluations could prove useful because nursery-derived isolates may be better adapted to nursery environments than commercially available biocontrol agents that were developed for other agricultural systems.

Several isolates of $F$. oxysporum, such as f. sp. lactucae, f. sp. melonis, and f. sp. lycopersici, which are pathogenic to lettuce, melon, and tomato, respectively, clustered with isolates that were nonpathogenic to Douglas-fir. Thus, it cannot be assumed that isolates nonpathogenic on Douglas-fir are also nonpathogenic on other plant species. Similarly, F. oxysporum f. sp. lilii isolates were shown to be highly pathogenic to lily, but were not pathogenic to gladiolus or tulip (2). Many additional studies have shown similar host specificity for $F$. oxysporum formae speciales (18).

Our highly virulent isolates clustered with isolates described as $F$. commune (Fig. 5), a recently characterized taxon closely related to $F$. oxysporum and $G$. fujikuroi species complexes, although independent of these species complexes (49). Because our highly virulent isolates appeared to be $F$. commune based on DNA sequences, morphological traits were examined to determine if these highly virulent isolates were similar to the morphological species description of $F$. commune. Morphological charac- teristics of $F$. commune include the formation of polyphialides, long, slender monophialides, and chlamydospores (49). Extensive microscopic examination revealed that only one of our highly virulent isolates produced a structure resembling a polyphialide while being grown on synthetic low-nutrient agar media under dark conditions (49). All Fusarium spp. isolates used in this study appeared morphologically similar regardless of pathogenicity. However, we conclude that our highly virulent isolates, previously classified as $F$. oxysporum, are $F$. commune based on definitive DNA sequence data.

To our knowledge, this is the first report that shows $F$. commune is a cause of Fusarium disease (root rot and damping-off) on Douglas-fir seedlings. Because isolates of $F$. commune in our study were morphologically indistinguishable from $F$. oxysporum, previous reports of disease on Douglas-fir caused by $F$. oxysporum may be attributable to what is now recognized as $F$. commune. Two isolates of $F$. commune used in this paper for comparison purposes, NRRL 22900 and NRRL 22903, were collected from Douglas-fir seedlings and previously classified as $F$. oxysporum based on morphological features $(10,49)$. In fact, the majority of newly recognized isolates of $F$. commune were previously classified as $F$. oxysporum (49). The morphological differences between these two species are few, and include plastic characteristics such as polyphialide production, which can be variable. It seems highly likely that $F$. commune taxon includes many isolates that are morphologically indistinguishable from $F$. oxysporum. At present, it appears that genetic characterization is the only reliable method to identify $F$. commune.

Pathogenic isolates from Douglas-fir have not been classified into a forma specialis because of the lack of evidence for host specialization within $F$. oxysporum associated with forest nurseries (8). The information presented here supports this conclusion. Moreover, it remains unclear whether $F$. oxysporum can be pathogenic to Douglas-fir or other conifers. Perhaps species that are morphologically similar to $F$. oxysporum, like $F$. commune, have been misidentified because genetic-based identification techniques were lacking. Several studies have shown that numerous

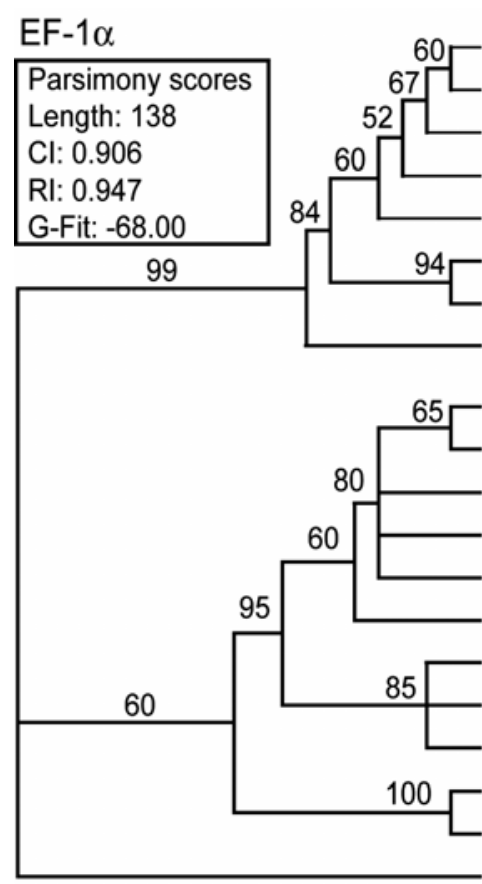

Parsimony

Fo-N1, N3, N5, N7, N8, N9, N10, N11, N12, N14, N15; Fo-L1, L3, L5; Fo-M1, M3; Fo-Fo47; F. o. f. sp. lactucae (0349) 99

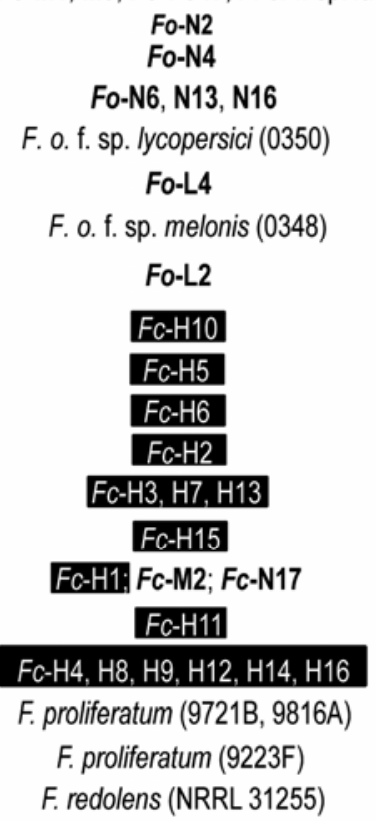

F. redolens (NRRL 31255)

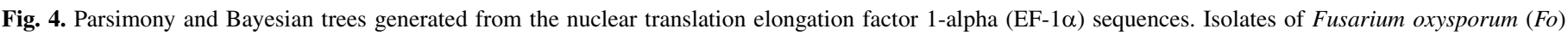

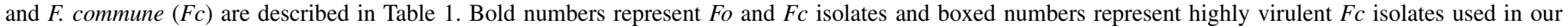

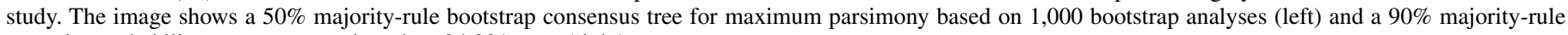
posterior probability consensus tree based on 24,001 trees (right). 
Fusarium spp., such as $F$. sporotrichioides, $F$. proliferatum, and $F$. circinatum, are capable of causing damping-off in conifers $(11,26,27,28,31,43,50)$. Studies examining the genetic association of these species would prove useful in understanding the complexity and relatedness of Fusarium spp. causing diseases of conifers.

Similarities between phylogram topologies of DNA sequences and AFLP data sets strengthen the conclusions of this study and indicate that distinct genetic differences exist between $F$. commune and $F$. oxysporum. In all analyses, separation of the highly virulent clade had over $80 \%$ bootstrap and posterior probability support. None of the AFLP profiles for isolates in our study were identical; however, isolates within a particular clade were 70 to 99\% similar. The fact that none of the AFLP profiles for the isolates examined were identical suggests that our test set did not contain clonal isolates. Thus, considerable genetic diversity among $F$. commune and $F$. oxysporum isolates was present within a single nursery. The high number of haplotypes and variation of AFLP profiles, within each clade, may indicate that the nursery has had numerous introductions of both $F$. oxysporum and $F$. commune over time. Pre-plant soil fumigation may not completely manage Fusarium spp. effectively $(13,20,21,40)$. In some situations, Fusarium propagules can infest soil and plant materials and may be introduced on seeds or other organic matter brought into nurseries $(31,43)$. The complexity of managing Fusarium spp. is greatly increased because of numerous pathogen introductions into nurseries and high genetic diversity among isolates. For this reason, an integrated approach for managing Fusarium spp. is prudent (12).

Isolates used in this study were collected from one particular nursery in Idaho; isolates from a wider range of forest nurseries would help determine if our results are applicable to other areas. Our long-term goal is to provide a basis for developing molecular

TABLE 2. Comparison of DNA sequence and amplified fragment length polymorphism (AFLP) tree statistics

\begin{tabular}{lccc}
\hline Analysis & $\begin{array}{c}\text { No. of unique } \\
\text { haplotypes }^{\mathrm{a}}\end{array}$ & $\begin{array}{c}\text { No. of } \\
\text { characters }\end{array}$ & $\begin{array}{c}\text { Synapomorphies/ } \\
\text { autapomorphies }\end{array}$ \\
\hline ITS+5.8S $^{\mathrm{b}}$ & 7 & 534 & $35 / 15$ \\
$\mathrm{mtSSU}^{\mathrm{c}}$ & 10 & 664 & $48 / 9$ \\
EF-1 $\alpha^{\mathrm{d}}$ & 20 & 661 & $71 / 45$ \\
$\mathrm{mtSSU}+\mathrm{EF}-1 \alpha$ & 35 & 1,287 & $117 / 84$ \\
AFLP & 48 & 146 & $124 / 17$ \\
\hline
\end{tabular}

a Number of unique haplotypes includes outgroups.

${ }^{\mathrm{b}} \mathrm{ITS}+5.8 \mathrm{~S}=$ internal transcribed spacers 1 and 2 including $5.8 \mathrm{~S}$ rDNA.

${ }^{\mathrm{c}} \mathrm{mtSSU}=$ mitochondrial small subunit rDNA.

${ }^{\mathrm{d}} \mathrm{EF}-1 \alpha=$ nuclear translation elongation factor 1-alpha.

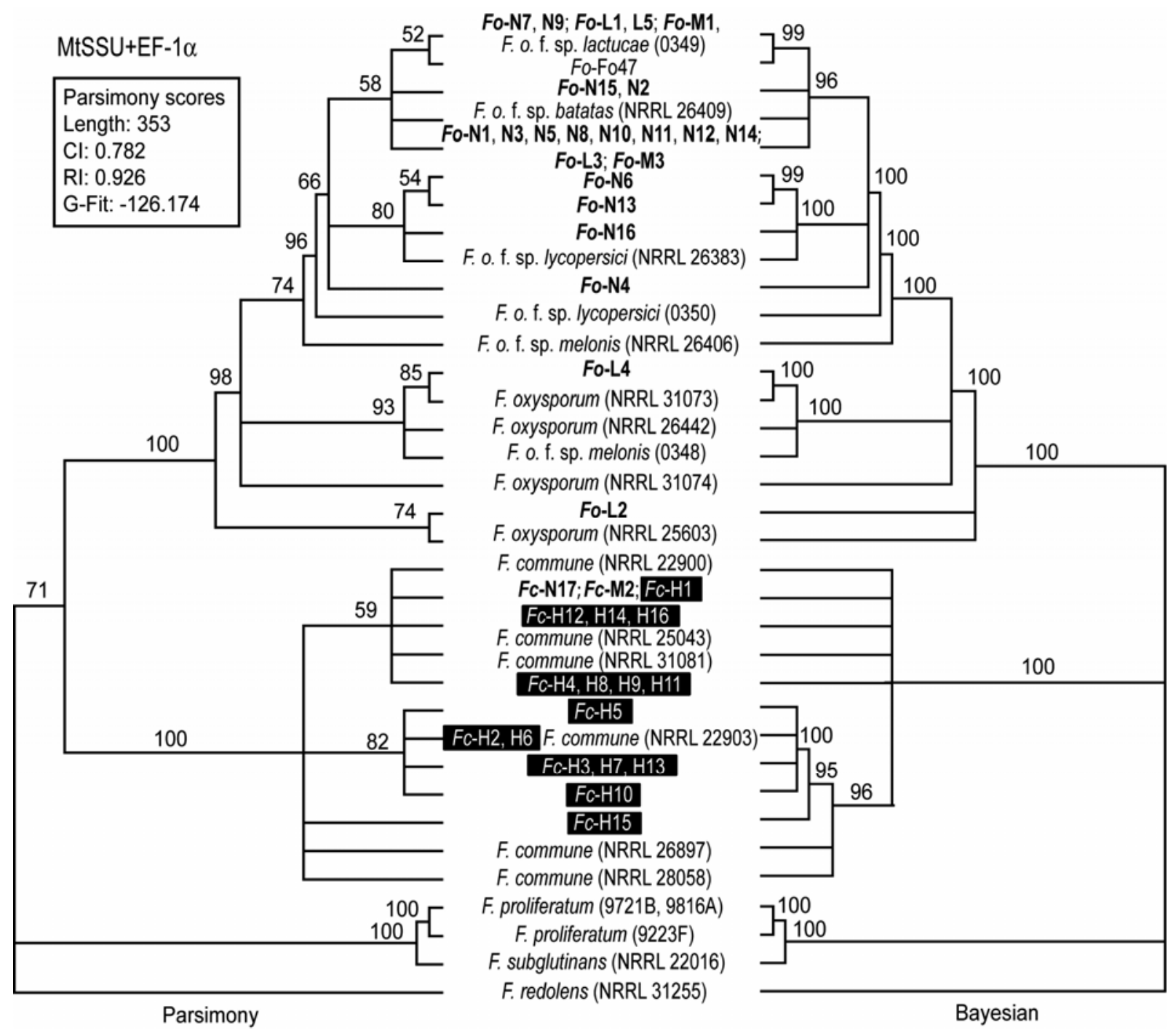

Fig. 5. Parsimony and Bayesian analyses generated from combined mitochondrial small subunit (mtSSU) rDNA and the nuclear translation elongation factor 1alpha $(\mathrm{EF}-1 \alpha)$ sequences. Isolates of Fusarium oxysporum $(F o)$ and $F$. commune $(F c)$ are described in Table 1 . Bold numbers represent $F o$ and $F c$ isolates and boxed numbers represent highly virulent $F c$ isolates used in our study. The image shows a $50 \%$ majority-rule bootstrap consensus for maximum parsimony analysis based on 1,000 bootstraps (left) and a 90\% majority-rule posterior probability consensus for Bayesian analysis based on 24,001 trees (right). 
markers for easy identification of highly virulent Fusarium isolates within nurseries that represent high risk to conifer seedlings. We have shown that several AFLP genetic markers and mtSSU sequences offer potential for development of such markers. After such markers are developed, further field testing will be required to validate their utility for characterizing pathogenic potential of Fusarium populations within forest nurseries.

\section{ACKNOWLEDGMENTS}

This work was supported by the U.S. Department of Agriculture (USDA) Forest Service, Rocky Mountain Research Station (RWU-4552: Microbial Processes as Ecosystem Regulators in Western Forests); National Virtual Center for Reforestation, Nurseries, and Genetic Resources; and Region 1 Forest Health Protection (Coeur d'Alene Field Office). We thank F. M. Dugan, B. A. Richardson, and J. R. Tonn for their comments on an earlier version of this manuscript; and Z. Abdo and J. W. Hanna for comments and useful statistical advice. Use of trade names does not constitute endorsement by the USDA Forest Service.

\section{LITERATURE CITED}

1. Appel, D. J., and Gordon, T. R. 1996. Relationships among pathogenic and nonpathogenic isolates of Fusarium oxysporum based on the partial sequence of the intergenic spacer region of the ribosomal DNA. Mol. Plant-Microbe Interact. 9:125-138.

2. Baayen, R. P., Förch, M. G., Waalwijk, C., Bonants, P. J. M., Löffler, H. J. M., and Roebroeck, E. J. A. 1998. Pathogenic, genetic, and molecular characterisation of Fusarium oxysporum f. sp. lilii. Eur. J. Plant Pathol. 104:887-894.

3. Baayen, R. P., O’Donnell, K., Bonants, P. J. M., Cigelnik, E., Kroon, L. P. N. M., Roebroeck, E. J. A., and Waalwijk, C. 2000. Gene genealogies and AFLP analyses in the Fusarium oxysporum complex identify monophyletic and nonmonophyletic formae speciales causing wilt and rot disease. Phytopathology 90:891-900.

4. Baayen, R. P., van Dreven, F., Krijger, M. C., and Waalwijk, C. 1997. Genetic diversity in Fusarium oxysporum f. sp. dianthi and Fusarium redolens f. sp. dianthi. Eur. J. Plant Pathol. 103:395-408.

5. Bao, J. R., Fravel, D. R., O’Neill, N. R., Lazarovits, G., and van Berkum, P. 2002. Genetic analysis of pathogenic and nonpathogenic Fusarium oxysporum from tomato plants. Can. J. Bot. 80:271-279.

6. Belabid, L., Baum, M., Fortas, Z., Bouznad, Z., and Eujayl, I. 2004. Pathogenic and genetic characterization of Algerian isolates of Fusarium oxysporum f. sp. lentis by RAPD and AFLP analysis. Afr. J. Biotech. 3:25-31.

7. Benhamou, N., Carand, C., and Goulet, A. 2002. Ability of nonpathogenic Fusarium oxysporum strain Fo47 to induce resistance against Pythium ultimum infection in cucumber. Appl. Environ. Microbiol. 68:4044-4060.

8. Bloomberg, W. J. 1981. Disease caused by Fusarium in forest nurseries. Pages 178-187 in: Fusarium: Diseases, Biology and Taxonomy. P. E. Nelson, T. A. Tousson, and R. J. Cook, eds. The Pennsylvania State University Press, University Park.

9. Cunningham, C. W. 1997. Can three incongruence tests predict when data should be combined? Mol. Biol. Evol. 14:733-740.

10. Donaldson, G. C. 1999. Development of a DNA based diagnostic assay for the detection and differentiation of pathogenic Fusarium oxysporum isolates from conifers in the Pacific Northwest. M.Sc. thesis. University of British Columbia, Vancouver, BC.

11. Donaldson, G. C., Ball, L. A., Axelrood, P. E., and Glass, N. L. 1995. Primer sets developed to amplify conserved genes from filamentous ascomycetes are useful in differentiating Fusarium species associated with conifer. Appl. Environ. Microbiol. 61:1331-1340.

12. Dumroese, R. K., and James, R. L. 2005. Root diseases in bareroot and container nurseries of the Pacific Northwest: Epidemiology, management, and effects on outplanting performance. New Forest 30:185-202.

13. Ebben, M. H., Gandy, G. D., and Spencer, D. M. 1983. Toxicity of methyl bromide to soil-borne fungi. Plant Pathol. 32:429-433.

14. Farris, J. S., Källersjö, M., Kluge, A. G., and Bult, C. 1994. Testing significance of incongruence. Cladistics 10:315-319.

15. Felsenstein, J. 2004. Inferring Phylogenies. Sinauer Associates, Inc., Sunderland, MA

16. Fuchs, J.-G., Moënne-Loccoz, Y., and Défago, G. 1997. Nonpathogenic Fusarium oxysporum strain Fo47 induces resistance to Fusarium wilt in tomato. Plant Dis. 81:492-496.

17. Gardes, M., and Bruns, T. D. 1993. ITS primers with enhanced specificity for basidiomycetes-application to the identification of mycorrhizae and rust. Mol. Ecol. 2:113-118
18. Gordon, T. R., and Martyn, R. D. 1997. The evolutionary biology of Fusarium oxysporum. Annu. Rev. Phytopathol. 35:111-128.

19. Hall, T. A. 1999. BioEdit: A user-friendly biological sequence alignment editor and analysis program for Windows 95/98/NT. Nucleic Acids Symp. Ser. 41:95-98.

20. Hansen, E. M., Myrold, D. D., and Hamm, P. B. 1990. Effects of soil fumigation and cover crops on potential pathogens, microbial activity, nitrogen availability, and seedling quality in conifer nurseries. Phytopathology 80:698-704.

21. Hildebrand, D. M., Stone, J. K., James, R. L., and Frankel, S. J. 2004 Alternatives to preplant soil fumigation for western forest nurseries. USDA For. Serv. PNW Res. Stn. Gen. Tech. Rep. PNW-GTR-608.

22. Hofsetter, V., Clémençon, H., Vilgalys, R., and Moncalvo, J.-M. 2002. Phylogenetics analyses of the Lyophylleae (Agaricales, Basidiomycota) based on nuclear and mitochondrial rDNA sequences. Mycol. Res. 106:1043-1059.

23. Huelsenbeck, J. P., and Ronquist, F. 2001. MrBayes: Bayesian inference of phylogenetic trees. Biometrics 17:754-755.

24. James, R. L. 1996. Technique for quantifying virulence of Fusarium and Cylindrocarpon spp. on conifer germinants. USDA For. Serv., Northern Region, For. Health Prot. Nursery Dis. Notes No. 132.

25. James, R. L., Dumroese, R. K., and Wenny, D. L. 1990. Approaches to integrated pest management of Fusarium root disease in container-grown seedlings. Pages 240-246 in: Target Seedling Symposium: Proc. combined meeting of the Western Forest Nursery Association and Intermountain Nursery Association. S. J. Rose and T. D. Landis, eds. USDA For. Serv. GTR RM-200, Fort Collins, CO.

26. James, R. L., Dumroese, R. K., and Wenny, D. L. 1995. Fusarium proliferatum is a common, aggressive pathogen of container-grown conifer seedlings. (Abstr.) Phytopathology 85:1129.

27. James, R. L., Dumroese, R. K., and Wenny, D. L. 1997. Pathogenicity of Fusarium proliferatum in container-grown Douglas-fir seedling. Pages 26-33 in: Proc. Third Meeting of IUFRO Working Party S7.03-04 (Disease and Insects in Forest Nurseries). R. L. James, ed. USDA For. Serv., Northern Region, For. Health Prot. Rep. 97-4.

28. James, R. L., and Perez, R. 1999. Pathogenic characteristics of Fusarium sporotrichioides isolated from inland Pacific Northwest forest nurseries. USDA For. Serv., Northern Region, For. Health Prot. Rep. 99-8.

29. James, R. L., Perez, R., Dumroese, R. K., and Wenny, D. L. 2000. Virulence of Fusarium oxysporum on Douglas-fir germinants: Comparison of isolates from nursery soil and roots of healthy and diseased seedlings. Pages 49-64 in: Proc. Fourth Meeting of IUFRO Working Party S7.03-04 (Disease and Insects in Forest Nurseries). Research Paper 781. A. Lilja and J. R. Sutherland, eds. Finnish Forest Research Institute, Helsinki, Finland.

30. Jeanmougin, F., Thompson, J. D., Gouy, M., Higgins, D. G., and Gibson, T. J. 1998. Multiple sequence alignment with Clustal X. Trends Biochem. Sci. 23:403-405.

31. Juzwik, J., Rugg, D. J., Menes, P. J., and Cease, K. R. 1995. Soil water management and Fusarium root rot in eastern white pine seedlings. Pages 76-1 and 76-2 in: Proc. 1995 Annual International Research Conference on Methyl Bromide Alternatives and Emissions Reduction. Elsevier, San Diego, CA.

32. Kauserud, H., and Schumacher, T. 2003. Genetic structure of Fennoscandian population of the threatened wood-decay fungus Fomitopsis rosea. Mycol. Res. 107:155-163.

33. Kim, M.-S., Klopfenstein, N. B., and Hamelin, R. C. 2005. Application of molecular genetic tools to studies of forest pathosystems. Pages 9-20 in: Forest Pathology-From Genes to Landscapes. J. E. Lundquist and R. C. Hamelin, eds. The American Phytopathological Society, St. Paul, MN.

34. Kim, M.-S., Klopfenstein, N. B., Hanna, J. W., and McDonald, G. I. 2006. Characterization of North American Armillaria species: Genetic relationships determined from ribosomal DNA sequences and AFLP markers. Forest Pathol. 36:145-164.

35. Kistler, H. C. 1997. Genetic diversity in the plant-pathogenic fungus $F u$ sarium oxysporum. Phytopathology 87:474-479.

36. Martin, F. N. 1990. Variation in the ribosomal DNA repeat unit within single-oospore isolates of the genus Pythium. Genome 33:585-591.

37. Mayék-Pérez, N., López-Castañeda, C., González-Chavira, M., GarciaEspinosa, R., Acosta-Gallegos, J., Martínez-de-la-Vega, O., and Simpson, J. 2001. Variability of Mexican isolates of Macrophomina phaseolina based on pathogenesis and AFLP genotype. Physiol. Mol. Plant Pathol. 59:13-19.

38. Mes, J. J., Weststeijn, E. A., Jerlaar, F., Jambalk, J. W., Haring, M. A., and Cornelissen, B. J. C. 1999. Biological and molecular characterization of Fusarium oxysporum f. sp. lycopersici divides race 1 isolates into separate virulence groups. Phytopathology 89:156-160.

39. Minin, V., Abdo, Z., Joyce, P., and Sullivan, J. 2003. Performance-based selection of likelihood models for phylogeny estimation. Syst. Biol. 52:674-683. 
40. Munnecke, D. E., Bricker, J. L., and Kolbezen, M. J. 1978. Comparative toxicity of gaseous methyl bromide to ten soilborne phytopathogenic fungi. Phytopathology 68:1210-1216.

41. Namiki, F., Shiomi, T., Nishi, K., Kayamura, T., and Tsuge, T. 1998. Pathogenic and genetic variation in the Japanese strains of Fusarium oxysporum f. sp. melonis. Phytopathology 88:804-810.

42. Nelson, P. E., Toussoun, T. A., and Marasas, W. F. O. 1983. Fusarium Species: An Illustrated Manual for Identification. Pennsylvania State University Press, University Park.

43. Ocamb, C. M., Juzwik, J., and Martin, F. B. 2002. Fusarium spp. and Pinus strobus seedlings: Root disease pathogens and taxa associated with seed. New Forests 24:67-69.

44. O'Donnell, K. 1992. Ribosomal DNA internal transcribed spacers are highly divergent in the phytopathogenic ascomycete Fusarium sambucinum (Gibberella pulicaris). Curr. Genet. 22:213-220.

45. O’Donnell, K., and Cigelnik, E. 1997. Two divergent intragenomic rDNA ITS2 types within a monophyletic lineage of the fungus Fusarium are nonorthologous. Mol. Phylogenet. Evol. 7:103-116.

46. O’Donnell, K., Kistler, H. C., Cigelnik, E., and Ploetz, R. C. 1998. Multiple evolutionary origins of the fungus causing Panama disease of banana: Concordant evidence from nuclear and mitochondrial gene genealogies. Proc. Natl. Acad. Sci. USA 95:2044-2049.

47. O’Donnell, K., Sutton, D. A., Rinaldi, M. G., Magnon, K. C., Cox, P. A., Revankar, S. G., Sanche, S., Geiser, D. M., Juba, J. H., van Burik, J. H., Padhye, A., Anaissie, E. J., Francesconi, A., Walsh, T. J., and Robinson, J. S. 2004. Genetic diversity of human pathogenic members of the Fusarium oxysporum complex inferred from multilocus DNA sequence data and amplified fragment length polymorphism analyses: Widespread clonal lineage and nosocomial origin. J. Clin. Microbiol. 42:5109-5120.
48. Simmons, M. P., and Ochoterena, H. 2000. Gaps as characters in sequence-based phylogenetic analyses. Syst. Biol. 49:369-381.

49. Skovgaard, K., Rosendahl, S., O’Donnell, K., and Hirenberh, H. I. 2003. Fusarium commune is a new species identified by morphological and molecular phylogenetic data. Mycologia 95:630-636.

50. Steenkamp, E. T., Wingfield, B. D., Coutinho, T. A., Wingfield, M. J., and Marasas, W. F. O. 1999. Differentiation of Fusarium subglutinans f. sp. pini by histone gene sequence data. Appl. Environ. Microbiol. 65:34013406.

51. Stewart, J. E., Kim, M.-S., James, R. L., Dumroese, R. K., and Klopfenstein, N. B. 2004. Molecular characterization of Fusarium oxysporum from tree nurseries: Tools for early detection of pathogens. (Abstr.) Phytopathology 94(suppl.):S99.

52. Vakalounakis, D. J., and Fragkiadakis, G. A. 1999. Genetic diversity of Fusarium oxysporum isolates from cucumber: Differentiation by pathogenicity, vegetative compatibility and RAPD fingerprinting. Phytopathology 89:161-168.

53. Vos, P., Hogers, R., Bleeker, M., Reijans, M., van de Lee, T., Homes, M., Frijters, A., Pot, J., Peleman, J., Kuiper, M., and Zabeau, M. 1995. AFLP A new technique for DNA fingerprinting. Nucleic Acids Res. 23:44074414.

54. White, T. J., Bruns, T., Lee, S., and Taylor, J. 1990. Amplification and direct sequencing of fungal ribosomal RNA gene for phylogenetics. Pages 315-322 in: PCR Protocols: A Guide to Methods and Applications. M. A. Innis, D. H. Gelfand, J. J., Sninsky, and T. J. White, eds. Academic Press, New York.

55. Woo, S. L., Zoina, A., Del Sorbo, G., Lorito, M., Nanni, B., Xala, F., and Noviello, C. 1996. Characterization of Fusarium oxysporum f. sp. phaseoli by pathogenic races, VCGs, RFLPs, and RAPD. Phytopathology 86:966-973. 